\title{
CrimRxiv
}

\section{OLDER ADULTS \\ RESPONSIBLE FOR TOTAL \\ GROWTH IN DRUG \\ ARRESTS}

John Jay Research and Evaluation Center

Published on: Nov 11, 2019

DOI: $10.21428 / c b 6 a b 371.8 b 42365 b$

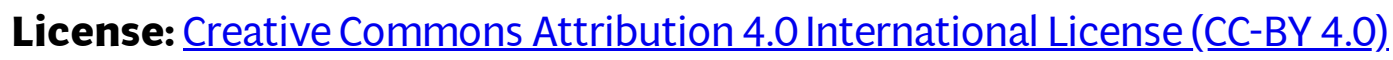


